\title{
Liver transplant outcomes in a Canadian First Nations population
}

\author{
M Zhang $M D^{1}$, J Uhanova MD PhD ${ }^{1}$, GY Minuk $M D^{1,2}$
}

\begin{abstract}
M Zhang, J Uhanova, GY Minuk. Liver transplant outcomes in a Canadian First Nations population. Can J Gastroenterol 2011;25(6):307-310.
\end{abstract}

BACKGROUND: A higher incidence of autoimmune disorders may predispose First Nations (FN) individuals to higher rates and more severe episodes of rejection, graft loss and mortality following liver transplantation for advanced liver disease.

METHODS: A retrospective review of patient outcomes in a single centre providing long-term follow-up care for $\mathrm{FN}$ and non-FN patients transplanted for advanced liver disease was conducted.

RESULTS: A total of $20 \mathrm{FN}$ and 129 non-FN charts were available for review. FN subjects were younger at transplantation (mean $[ \pm \mathrm{SD}]$ age $32.4 \pm 4.1$ years versus $46.3 \pm 1.4$ years; $\mathrm{P}=0.00005$ ), less often male ( $35 \%$ versus $58 \% ; \mathrm{P}=0.05$ ), more commonly transplanted for autoimmune hepatitis ( $30 \%$ versus $4.7 \%$; $\mathrm{P}=0.006)$, less often from urban residences ( $25 \%$ versus $74 \% ; \mathrm{P}=0.0001$ ) and less compliant with medical care $(20 \%$ versus $80 \% ; \mathrm{P}=0.007)$. After a mean follow-up period of $11.0 \pm 1.5$ years and $8.4 \pm 0.5$ years in $\mathrm{FN}$ and non-FN subjects, respectively, the incidence and severity of rejection, graft and patient survival were similar between cohorts.

CONCLUSION: Although demographic profiles, nature of the underlying disease and compliance differed, the rates and severity of rejection, graft and patient survival were similar in FN and non-FN patients who underwent liver transplantation for advanced liver disease.

Key Words: First Nations; Graft survival; Indigenous; Liver transplantation; Patient survival; Rejection

$\mathrm{L}^{\mathrm{i}}$ iver transplantation has become the treatment of choice for patients with decompensated disease (1). Although outcomes for elective transplants are excellent, acute and chronic rejection, recurrent disease and the development of various comorbidities can result in adverse outcomes.

There are conflicting data regarding whether ethnicity influences outcome following organ transplantation $(2,3)$. In studies in which adverse outcomes have been described in indigenous or minority populations, it has been difficult to discern whether ethnicity per se or differences in socioeconomic status, proximity to the transplant centre (rural versus urban) or compliance with medical care were responsible for the findings.

Immune-mediated disorders are more common and severe in Canada's First Nations (FN) population (4-8). This immune 'hyper-reactivity' may relate to a genetic predisposition in which anti-inflammatory cytokine synthesis and release is attenuated (9). The resulting increase in the pro/anti-inflammatory ratio raises concerns regarding an increased risk of rejection after organ transplantation in the FN population. Indeed, higher rejection and lower long-term survival rates have been described in Canadian Aboriginal children and adults following kidney transplantation $(10,11)$. Whether similar findings apply to liver transplant recipients remains to be determined.

In the present study, we retrospectively documented and compared the demographic features and clinical outcomes in FN and

\section{Les issues de la transplantation hépatique au sein d'une population des Premières nations}

HISTORIQUE : Une plus forte incidence de troubles auto-immuns peut prédisposer les habitants des Premières nations $(\mathrm{PN})$ à des taux plus élevés et de plus graves épisodes de rejet, de perte de la greffe et de mortalité après une greffe hépatique effectuée pour traiter une maladie hépatique avancée.

MÉTHODOLOGIE : Les chercheurs ont mené une analyse rétrospective des issues des patients dans un seul centre offrant des soins de suivi à long terme pour les patients des $\mathrm{PN}$ et ne faisant pas partie des PN ayant reçu une greffe en raison d'une malade hépatique avancée.

RÉSULTATS : Au total, 20 graphiques de PN et 129 graphiques de personnes ne faisant pas partie des PN ont pu être analysés. Les sujets des PN étaient plus jeunes au moment de la greffe (âge moyen [ \pm ÉT] de $32,4 \pm 4,1$ ans par rapport à 46,3 $\pm 1,4$ ans; $\mathrm{P}=0,00005)$, moins souvent de sexe masculin ( $35 \%$ par rapport à $58 \% ; \mathrm{P}=0,05)$, plus souvent traités à cause d'une hépatite auto-immune (30\% par rapport 4,7\%; $\mathrm{P}=0,006)$, moins souvent d'un milieu urbain ( $25 \%$ par rapport à $74 \%$; $\mathrm{P}=0,0001$ ) et moins respectueux des soins médicaux (20\% par rapport à $80 \% ; \mathrm{P}=0,007$ ). Après un suivi moyen de $11,0 \pm 1,5$ ans et $8,4 \pm 0,5$ ans chez des sujets des PN et ne faisant pas partie des PN, respectivement, l'incidence et la gravité du rejet, la survie de la greffe et la survie des patients étaient similaires entre les cohortes.

CONCLUSION : Même si les profils démographiques et les taux d'adhésion au traitement différaient, les taux et la gravité du rejet, de survie de la greffe et de survie des patients étaient similaires chez les patients des PN et ne faisant pas partie des PN qui avaient subi une greffe hépatique en raison d'une maladie hépatique avancée.

non-FN patients who underwent liver transplantation for end-stage liver disease over a 22-year period.

\section{Study population}

\section{METHODS}

Patients were identified using a computerized search of the Section of Hepatology database for all patients seen on at least one occasion in the Adult Liver Post-Transplant Outpatient Clinic at the Health Sciences Centre (Winnipeg, Manitoba) between January 1, 1986 (establishment of the clinic), and December 31, 2009. Patients younger than 16 years of age were excluded.

Subjects were defined as FN if they were registered under the Indian Act of Canada (ie, possessed a treaty number) or, if not registered (approximately $30 \%$ of the FN population), by self-report of their ethnicity.

Episodes of rejection were defined as an acute increase in serum alkaline phosphatase levels of higher than twice the upper limit of normal, or baseline values with no alternative explanation for the increase such as concomitant bacterial/viral infections, anatomical obstructions of the biliary tract or introduction of a new/potentially hepatotoxic medication and a return to baseline serum alkaline phosphatase levels with an increase in immunosuppression. In cases failing to respond to increases in immunosuppression, liver histology was required to confirm the diagnosis.

${ }^{1}$ Department of Medicine; ${ }^{2}$ Department of Pharmacology and Therapeutics, University of Manitoba, Winnipeg, Manitoba

Correspondence: Dr GY Minuk, John Buhler Research Centre, University of Manitoba, 715 McDermot Avenue, Winnipeg, Manitoba R3E 3P4.

Telephone 204-789-3204, fax 204-789-3987,e-mail gminuk@cc.umanitoba.ca

Received for publication November 1, 2010. Accepted November 11, 2010 
TABLE 1

Demographic data of First Nations (FN) and non-FN subjects from Manitoba undergoing liver transplantation

\begin{tabular}{lccccc}
\hline & $\begin{array}{c}\text { FN } \\
(\mathbf{n}=\mathbf{2 0})\end{array}$ & $\%$ & $\begin{array}{c}\text { Non-FN } \\
(\mathbf{n = 1 2 9})\end{array}$ & $\%$ & $\mathbf{P}$ \\
\hline Age at Tx, years & $32.4 \pm 4.1$ & - & $46.3 \pm 1.4$ & - & 0.0005 \\
Age at last F/U, years & $43.4 \pm 3.4$ & - & $54.8 \pm 1.3$ & - & 0.002 \\
Males, n & 7 & 35.0 & 75 & 58.1 & 0.05 \\
Female/male ratio, $\mathrm{n} / \mathrm{n}$ & $13 / 7$ & 1.9 & $54 / 75$ & 0.7 & - \\
Urban, n & 5 & 25.0 & 96 & 74.4 & 0.0001 \\
Years of F/U post-Tx & $11.0 \pm 1.5$ & - & $8.4 \pm 0.5$ & - & 0.112 \\
\hline
\end{tabular}

Data presented as mean \pm standard error unless otherwise indicated. $F / U$ Follow-up; Tx Transplantation

TABLE 2

Pretransplant underlying liver diseases in First Nations (FN) and non-FN subjects from Manitoba undergoing liver transplantation

\begin{tabular}{|c|c|c|c|c|}
\hline & $\begin{array}{c}\text { FN } \\
(n=20)\end{array}$ & $\begin{array}{l}\text { Non-FN } \\
(n=129)\end{array}$ & $\mathbf{P}$ & $\begin{array}{c}\text { Total } \\
(n=149)\end{array}$ \\
\hline Primary biliary cirrhosis & $3(15.0)$ & $27(20.9)$ & & $30(20.1)$ \\
\hline Primary sclerosing cholangitis & - & $19(14.7)$ & & $19(12.8)$ \\
\hline Fulminant hepatic failure & $3(15.0)$ & $11(8.5)$ & & $14(9.4)$ \\
\hline Hepatitis C virus & $3(15.0)$ & $12(9.3)$ & & $14(9.4)$ \\
\hline Autoimmune hepatitis & $6(30.0)$ & $6(4.7)$ & 0.006 & $12(8.1)$ \\
\hline Alcohol abuse & - & $11(8.5)$ & & $11(7.4)$ \\
\hline Cryptogenic & $1(5.0)$ & $7(5.4)$ & & $8(5.4)$ \\
\hline Hepatitis C virus/HCC & - & $8(6.2)$ & & $8(5.4)$ \\
\hline Congenital & $4(20.0)$ & $4(3.1)$ & & $3(2.0)$ \\
\hline Nonalcoholic steatohepatitis & - & $3(2.3)$ & & $3(2.0)$ \\
\hline $\mathrm{HCC}$ & - & $2(1.6)$ & & $2(1.3)$ \\
\hline Hepatitis B virus/HCC & - & $3(2.3)$ & & $3(2.0)$ \\
\hline Other & - & $14(10.8)$ & & $3(2.0)$ \\
\hline
\end{tabular}

Data presented as $n$ (\%) unless otherwise indicated. HCC Hepatocellular carcinoma

Patients were considered to be noncompliant if they failed to appear for scheduled outpatient clinic visits on at least two consecutive occasions.

\section{Statistical analysis}

Categorical variables were evaluated using $\chi^{2}$ analysis. The $\chi^{2}$ test of association was used to examine differences in demographic factors, pretransplant diagnosis, treatment regimens, etc. The Armitage test was used to examine linear trends in proportions. Continuous variables (such as laboratory test values) were assessed using the Student's $t$ test for differences between means or the Mann-Whitney $U$ test for differences in medians (as appropriate). The $95 \%$ CIs for means and for significant differences were also calculated. Kaplan-Meier product-limit survival distribution and survival curves were generated to estimate rejection-free and overall survival. Rates of acute rejection were calculated per 1000 person-years of follow-up post-transplant. Statistical significance for all analyses was set at $\mathrm{P}<0.05$.

Statistical analysis was performed using NCSS statistical software (NCSS \& PASS, 2004, USA [www.ncss.com]).

\section{RESULTS}

A total of 149 transplant recipients were identified (20 FN and 129 nonFN). The majority of transplant procedures were performed in London, Ontario (in excess of $75 \%$ for both groups). Deceased donor liver transplants were performed in $100 \%$ of $\mathrm{FN}$ and $94 \%$ of non-FN subjects $(\mathrm{P}=0.25)$.

The demographic features of the two cohorts are summarized in Table 1. The mean $( \pm \mathrm{SD})$ age at transplantation was significantly lower in $\mathrm{FN}$ than in non-FN patients $(32.4 \pm 4.1$ years versus $46.3 \pm 1.4$ years, respectively;
TABLE 3

Immunosuppressive regimens used in First Nations (FN) and non-FN subjects from Manitoba undergoing liver transplantation

\begin{tabular}{|c|c|c|c|c|}
\hline & $\begin{array}{c}\text { FN } \\
(n=20)\end{array}$ & $\begin{array}{l}\text { Non-FN } \\
(n=129)\end{array}$ & $\mathbf{P}$ & $\begin{array}{c}\text { Total } \\
(n=149)\end{array}$ \\
\hline \multicolumn{5}{|l|}{ Induction } \\
\hline Azathioprine & $4(20.0)$ & $7(5.4)$ & 0.020 & $11(7.4)$ \\
\hline СуA & $11(55.0)$ & $55(42.6)$ & 0.300 & $66(44.3)$ \\
\hline Mycophenolate & $5(25.0)$ & $41(31.8)$ & 0.540 & $46(30.9)$ \\
\hline Sirolimus & $0(0.0)$ & $9(7)$ & 0.222 & $9(6.0)$ \\
\hline Steroids & $20(100.0)$ & $123(95.3)$ & 0.320 & $143(96.0)$ \\
\hline Tacrolimus & $9(45.0)$ & $67(51.9)$ & 0.560 & 76 (51.0) \\
\hline \multicolumn{5}{|l|}{ Maintenance } \\
\hline Azathioprine & $4(20.0)$ & $9(7)$ & 0.055 & $13(8.7)$ \\
\hline CyA & $6(30.0)$ & $36(27.9)$ & 0.847 & $42(28.2)$ \\
\hline Mycophenolate & $10(50.0)$ & $46(35.7)$ & 0.218 & $56(37.6)$ \\
\hline Sirolimus & $2(10.0)$ & $17(13.2)$ & 0.692 & 19 (12.8) \\
\hline Steroids & $3(15.0)$ & $9(7)$ & 0.220 & $12(8.1)$ \\
\hline Tacrolimus & $12(60.0)$ & $78(60.5)$ & 0.968 & $90(60.4)$ \\
\hline \multicolumn{5}{|l|}{ Change from to } \\
\hline Change of regimen & $7(35.0)$ & $33(25.6)$ & 0.388 & $40(26.8)$ \\
\hline CyA to sirolimus & $1(5.0)$ & $10(7.8)$ & 0.983 & $11(7.4)$ \\
\hline CyA to tacrolimus & $4(20.0)$ & $20(15.5)$ & 0.856 & $24(16.1)$ \\
\hline Tacrolimus to CyA & $1(5.0)$ & $2(1.6)$ & 0.868 & $3(2.0)$ \\
\hline Add sirolimus & $1(5.0)$ & $1(0.8)$ & 0.627 & $2(1.3)$ \\
\hline
\end{tabular}

$\mathrm{P}=0.0005)$ and fewer $\mathrm{FN}$ recipients were men ( $35 \%$ versus $58 \% ; \mathrm{P}=0.05$ ). There were also fewer urban residents among the FN cohort (25\% versus $74 \% ; \mathrm{P}=0.0001)$. The length of the mean follow-up period was similar $(11.0 \pm 1.5$ years for $\mathrm{FN}$ versus $8.4 \pm 0.5$ years for non-FN).

The underlying liver diseases resulting in a need for transplantation are presented in Table 2. Overall, primary biliary cirrhosis was most common $(20.1 \%)$ followed by primary sclerosing cholangitis $(12.8 \%)$, idiopathic fulminant hepatic failure $(9.4 \%)$ and chronic hepatitis C (9.4\%). Only autoimmune hepatitis was disproportionally represented among the two cohorts, being significantly more common in $\mathrm{FN}$ subjects ( $30 \%$ versus $4.7 \% ; \mathrm{P}=0.006)$.

With the exception of azathioprine being used more often in FN subjects during the early post-transplant period, the immunosuppressive regimens used both at induction and for maintenance were similar in the two cohorts (Table 3).

There was no difference in the percentage of subjects who developed at least one episode of rejection (FN: $50 \%$ versus non-FN: $53 \% ; \mathrm{P}=0.266$ ). Among the $10 \mathrm{FN}$ and 45 non-FN subjects who experienced rejection, two episodes were documented in two patients $(20 \%)$ and $10(22 \%)$, three in one $(10 \%)$ and seven $(16 \%)$, four in one $(10 \%)$ and two $(4.4 \%)$, five in one $(10 \%)$ and three $(6.7 \%)$, six in one $(10 \%)$ and two $(4.4 \%)$, and eight in zero $(0 \%)$ and one $(2.2 \%)$ patients, respectively. These differences were not statistically significant. The calculated rates of rejection were also similar: 118.7/1000 personyears in $\mathrm{FN}$ and 95.9/1000 person-years in non-FN subjects $(\mathrm{P}=0.754)$.

The results of liver biochemistry testing performed during the most severe episode of rejection are provided in Table 4. Neither the extent of hepatocellular injury (aminotransferase values) nor cholestatic enzyme abnormalities (alkaline phosphatase and gamma-glutamyl transferase) differed in the two cohorts. Liver function tests (serum bilirubin, international normalized ratio of prothrombin times and albumin) were also similar in the two groups.

Liver biopsies were performed to confirm rejection in $30 \%$ of $\mathrm{FN}$ and $26.6 \%$ of non-FN patients $(\mathrm{P}=0.9)$. There was no difference in the severity of rejection as described by the various grading systems that were in place at the time over the 22-year study period (data not shown). 
TABLE 4

Maximum liver biochemistry results during rejection episodes in First Nations (FN) and non-FN subjects from Manitoba undergoing liver transplantation

\begin{tabular}{|c|c|c|c|c|c|c|c|c|c|c|c|}
\hline \multirow[b]{2}{*}{ Variable } & \multirow[b]{2}{*}{ Group } & \multirow[b]{2}{*}{$\mathbf{n}$} & \multirow[b]{2}{*}{ Mean } & \multirow[b]{2}{*}{ SD } & \multirow[b]{2}{*}{ SE } & \multicolumn{2}{|c|}{$95 \% \mathrm{Cl}$} & \multicolumn{2}{|c|}{ Range } & \multirow[b]{2}{*}{ Median } & \multirow[b]{2}{*}{$\mathbf{P}$} \\
\hline & & & & & & Lower & Upper & Minimum & Maximum & & \\
\hline \multirow[t]{2}{*}{$\overline{A L T},<25 \mathrm{U} / \mathrm{L}$} & Non-FN & 45 & 303.0 & 369.9 & 55.1 & 191.9 & 414.1 & 19 & 1783 & 161 & 0.253 \\
\hline & $\mathrm{FN}$ & 10 & 205.9 & 196.0 & 62.0 & 65.7 & 346.1 & 20 & 640 & 152 & \\
\hline \multirow[t]{2}{*}{ AST, 10-32 U/L } & Non-FN & 45 & 178.9 & 210.9 & 31.4 & 115.6 & 242.3 & 20 & 1040 & 85 & 0.836 \\
\hline & $\mathrm{FN}$ & 10 & 164.1 & 161.1 & 50.9 & 48.9 & 279.3 & 21 & 476 & 83 & \\
\hline \multirow[t]{2}{*}{ GGT, 5-29 U/L } & Non-FN & 44 & 536.9 & 588.2 & 88.7 & 358.1 & 715.7 & 84 & 2772 & 277 & 0.440 \\
\hline & $\mathrm{FN}$ & 9 & 412.6 & 388.8 & 129.6 & 113.7 & 711.4 & 27 & 1124 & 185 & \\
\hline \multirow[t]{2}{*}{ AP, 30-120 U/L } & Non-FN & 45 & 487.8 & 560.0 & 83.5 & 319.5 & 656.0 & 149 & 3060 & 354 & 0.702 \\
\hline & $\mathrm{FN}$ & 10 & 418.6 & 155.6 & 49.2 & 307.3 & 529.9 & 182 & 583 & 478.5 & \\
\hline \multirow{2}{*}{$\begin{array}{l}\text { Total bilirubin, } \\
2-20 \mu \mathrm{mol} / \mathrm{L}\end{array}$} & Non-FN & 45 & 39.9 & 75.2 & 11.2 & 17.3 & 62.5 & 1 & 373 & 15 & 0.886 \\
\hline & $\mathrm{FN}$ & 10 & 43.5 & 55.4 & 17.5 & 3.9 & 83.1 & 6 & 173 & 17.5 & \\
\hline \multirow[t]{2}{*}{ INR, 0.9-1.1 } & Non-FN & 44 & 1.2 & 0.4 & 0.1 & 1.0 & 1.3 & 0.9 & 3.5 & 1.1 & 0.652 \\
\hline & $\mathrm{FN}$ & 10 & 1.1 & 0.3 & 0.1 & 0.9 & 1.3 & 0.9 & 1.8 & 1.05 & \\
\hline \multirow{2}{*}{$\begin{array}{l}\text { Albumin, } \\
\text { 33-45 g/L }\end{array}$} & Non-FN & 43 & 35.5 & 5.0 & 0.8 & 34.0 & 37.1 & 23 & 45 & 36 & 0.575 \\
\hline & $\mathrm{FN}$ & 9 & 33.6 & 5.3 & 1.8 & 29.5 & 37.6 & 26 & 45 & 32 & \\
\hline
\end{tabular}

ALT Alanine aminotransferase; AP Alkaline phosphatase; AST Aspartate aminotransferase; GGT Gamma-glutamyl transferase; INR International normalized ratio of prothrombin times; SE Standard error

TABLE 5

Causes of death in First Nations (FN) and non-FN subjects from Manitoba undergoing liver transplantation

\begin{tabular}{lcc}
\hline & FN (n=20) & Non-FN (n=129) \\
\hline Decompensated cirrhosis & $0(0)$ & $4(3.1)$ \\
Chronic rejection & $1(5)$ & $1(0.8)$ \\
Gastrointestinal bleed & $0(0)$ & $1(0.8)$ \\
Sepsis & $0(0)$ & $2(1.6)$ \\
Multiorgan failure & $0(0)$ & $2(1.6)$ \\
Recurrent hepatocellular carcinoma & $0(0)$ & $1(0.8)$ \\
Breast cancer & $0(0)$ & $4(3.1)$ \\
Colon cancer & $0(0)$ & $1(0.8)$ \\
Lung cancer & $0(0)$ & $2(1.6)$ \\
Unknown & $5(25)$ & $0(0)$ \\
\hline
\end{tabular}

Data presented as $n$ (\%)

Noncompliance was more common in the FN group (10 of 20 [50\%]) than in the non-FN group $(15$ of $129[12 \%])(P<0.01)$. It was the perceived explanation for rejection in the majority of FN subjects (eight of 10 [80\%] versus nine of 45 [20\%]; $\mathrm{P}=0.007$ ).

There were six deaths (30\%) in the FN and $26(20.2 \%)$ in the nonFN cohorts over the 22-year follow-up period $(\mathrm{P}=0.318)$. The causes of death are listed in Table 5. Only one death in each cohort was ascribed to chronic rejection. The high percentage of unknown cause of death in FN subjects $(25 \%)$ appeared to correlate with rural/remote residence.

Rejection-free and overall survival curves are provided in Figures 1 and 2, respectively. The mean rejection-free survival was $9.1 \pm 1.6$ years and $7.6 \pm 0.6$ years $(\mathrm{P}=0.39)$, and overall survival was $11.0 \pm 1.5$ years and $8.4 \pm 0.5$ years for $\mathrm{FN}$ and non-FN subjects, respectively. These differences were not statistically significant. There was only one graft loss - in a nonFN subject with Wilson's disease who had been transplanted 23 years earlier.

The outcomes of patients transplanted for autoimmune hepatitis did not differ from those transplanted for other conditions (data not shown).

\section{DISCUSSION}

The principal results of the present study indicate that the incidence of rejection, graft and patient survival between this particular FN population and a non-FN population undergoing liver transplantation for decompensated liver disease are similar. The results also indicate that FN subjects tend to be younger, more often women, tend to reside in rural communities, are more commonly transplanted for

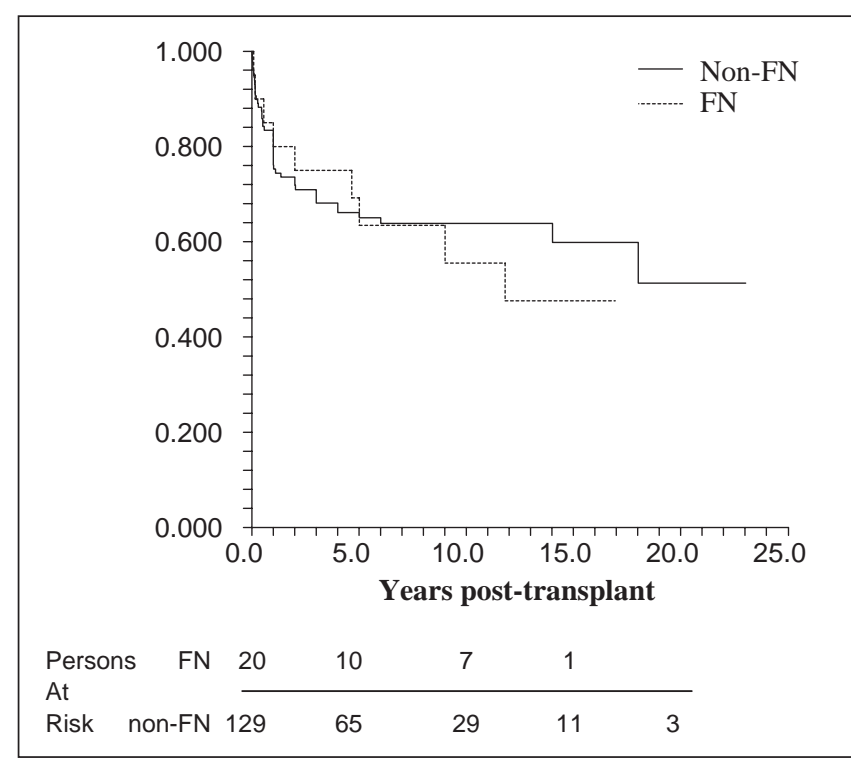

Figure 1) Kaplan-Meier analysis of rejection-free survival rates in 20 First Nations (FN) and 129 non-FN adult subjects following liver transplantation for advanced liver disease. The differences observed were not statistically significant

autoimmune hepatitis and are less compliant in the post-transplant period than non-FN subjects.

As indicated earlier, there is much uncertainty regarding whether ethnicity is predictive of outcome following liver transplantation. In a study analyzing United Network for Organ Sharing data, Neff et al (12) described one-, three-, five- and 10-year graft and patient survival rates that were significantly lower in 2963 African Americans compared with 29,430 Caucasian and 4369 Hispanic patients (12). Similarly, Devlin et al (13) described higher rejection rates (12.6\% versus $5.9 \%)$ and lower three-year survival rates (47\% versus 60\%) in non-Caucasian versus Caucasian European liver transplant recipients (13). Conversely, no significant differences in survival following transplantation were reported by Forde et al (14) in 927 subjects (82\% white, 13\% black and $5 \%$ Asian) with acute liver failure. Lee et al (15) described similar rates of graft and patient survival one, five and 10 years post-transplantation in 135 African Americans, 2448 Caucasians and 240 members of other 


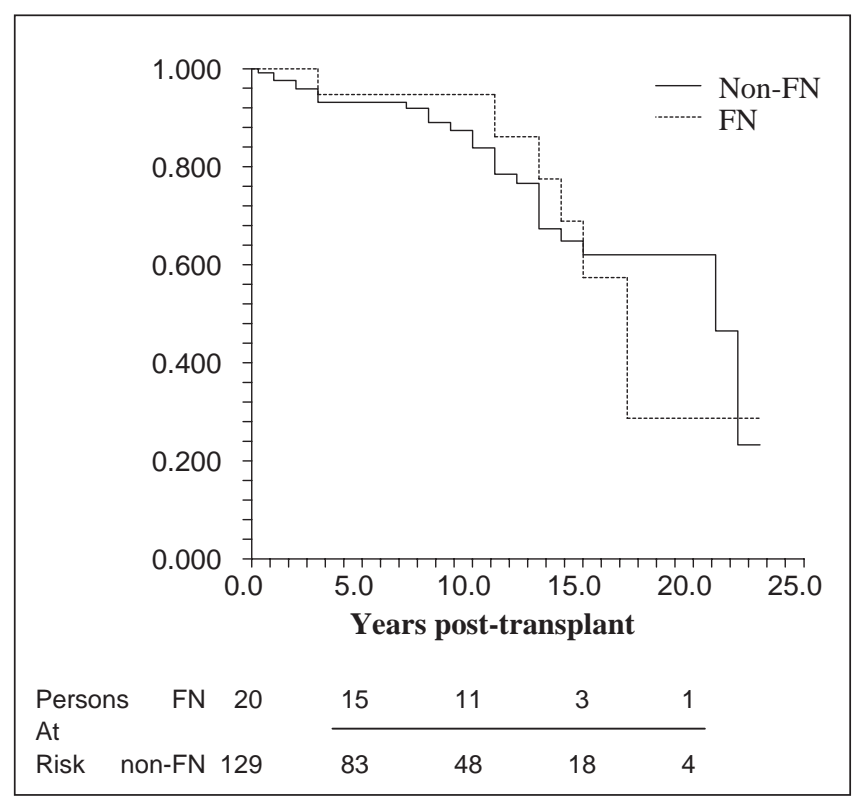

Figure 2) Kaplan-Meier overall survival curves in 20 First Nations (FN) and 129 non-FN adult subjects following liver transplantation for advanced liver disease. The differences observed were not statistically significant

races during their study period (1985 to 2000). Thus, our findings are consistent with the results of the latter two studies and argue against ethnicity playing an important role in the outcome of liver transplantation for patients with advanced disease.

The fact that FN liver transplant recipients were more often women, younger and had a higher prevalence of autoimmune hepatitis before transplantation was not surprising and were likely related findings. Indeed, our group and others have described a high prevalence of both autoimmune hepatitis and primary biliary cirrhosis in FN populations; both disorders are more common in women $(16,17)$. Moreover, at least in autoimmune hepatitis, the disease appears to be more aggressive in FN subjects, which might help to explain the younger age of FN recipients (16). Further contributing to the sex and age findings

\section{REFERENCES}

1. Skagen C, Lucey M, Said A. Liver transplantation: An update 2009. Curr Opin Gastroenterol 2009;25:202-8.

2. Kemmer N, Neff GW. Liver transplantation in the ethnic minority population: Challenges and prospects. Dig Dis Sci 2010;55:883-9.

3. Isaacs R. Ethical implications of ethnic disparities in chronic kidney disease and kidney transplantation. Adv Ren Replace Ther 2004;11:55-8

4. Arbour L, Rupps R, Field L, et al. Characteristics of primary biliary cirrhosis in British Columbia's First Nations population. Can J Gastroenterol 2005;19:305-10.

5. Hitchon CA, Peschken CA. Sm antibodies increase risk of death in systemic lupus erythematosus. Lupus 2007;16:186-94.

6. Svenson LW, Warren S, Warren KG, Metz LM, Patten SB, Schopflocher DP. Prevalence of multiple sclerosis in First Nations people of Alberta. Can J Neurol Sci 2007;34:175-80.

7. Yoshida EM, Riley M, Arbour LT. Autoimmune liver disease and the Canadian First Nations Aboriginal Communities of British Columbia's Pacific Northwest. World J Gastroenterol 2006;12:3625-7.

8. Chung HV, Riley M, Ho JK, et al. Retrospective review of pediatric and adult autoimmune hepatitis in two quaternary care centres in British Columbia: Increased prevalence seen in British Columbia's First Nations community. Can J Gastroenterol 2007;21:565-8.

9. Aborsangaya KB, Dembinski I, Khatkar S, Alphonse MP, Nickerson P, Rempel JD. Impact of aboriginal ethnicity on HCV core-induced IL-10 synthesis: Interaction with IL-10 gene polymorphisms. Hepatology 2007;45:623-30.

10. Weber CL, Rush DN, Jeffery JR, Cheang M, Karpinski ME. Kidney transplantation outcomes in Canadian aboriginals. Am J Transplant 2006;6:1875-81. are the results of previous studies of patients with chronic hepatitis $\mathrm{C}$ $(18,19)$ (another common cause for transplantation), which documented that $\mathrm{FN}$ patients with hepatitis $\mathrm{C}$ tend to be more often female and younger than non-FN patients who are infected.

The reason(s) why FN patients exhibited significantly higher rates of noncompliance remains to be determined. One possible explanation relates to these populations more commonly residing in rural (and remote) areas, which could influence attendance at follow-up clinics (20). Given that noncompliance was the suspected cause for the majority of rejection episodes, this represents a clear target for intervention which, hopefully, will result in fewer future episodes of rejection in FN recipients.

There are several limitations to the present study beyond those commonly associated with a retrospective study design. First, the number of subjects was small. As a result, matching for age, sex and underlying liver disease between FN and non-FN subjects was not feasible. Second, episodes of rejection were defined on the basis of changes in liver biochemistry and response to increases in immunosuppressive therapy, with only atypical or nonresponsive episodes being confirmed histologically. Third, we were unable to capture data from the various transplant centres where the procedures were performed (and the patients hospitalized for the initial two to four weeks post-transplant before being transferred back to the study centre). Thus, episodes of rejection in the immediate post-transplant period were not included in the analyses. Finally, the FN subjects involved in the current study were largely Ojibwa-Cree, whether these findings can be extrapolated to other FN populations remains to be determined.

\section{CONCLUSION}

The results of the present study indicate that despite different demographics, more rural residences, a higher incidence of autoimmune liver disorders and less compliance with medical care in the follow-up period, FN patients have similar rates of rejection, graft and patient survival to non-FN subjects following liver transplantation for advanced liver disease.

ACKNOWLEDGEMENTS: The authors thank Drs B Rosser, E Renner and K Kaita, Ms R Baslewski and V Strick for their care of the patients, and Ms R Vizniak for her prompt and accurate typing of the manuscript.

11. Matsuda-Abedini M, Al-AlSheikh K, Hurley RM, Matsell DG, Chow J, Carter JE, Lirenman DS. Outcome of kidney transplantation in Canadian Aboriginal children in the province of British Columbia. Pediatr Transplant 2009;13:856-60.

12. Neff GW, Kemmer N, Kaiser T, Zacharias V, Majoras N, Safdar K. Outcomes in adult and pediatric liver transplantation among various ethnic groups. Transplant Proc 2007;39:3204-6.

13. Devlin JJ, O'Grady JG, Tan KC, Calne RY, Williams R. Ethnic variations in patient and graft survival after liver transplantation. Identification of a new risk factor for chronic allograft rejection. Transplantation 1993:46:1381-4.

14. Forde KA, Reddy KR, Troxel AB, Sanders CM, Lee WM. Racial and ethnic differences in presentation, etiology, and outcomes of acute liver failure in the United States. Clin Gastroenterol Hepatol 2009;7:1121-6.

15. Lee TH, Shah N, Pedersen RA, et al. Survival after liver transplantation: Is racial disparity inevitable? Hepatology 2007;46:1491-7.

16. Minuk GY, Liu S, Kaita K, et al. Autoimmune hepatitis in a North American Aboriginal/First Nations population. Can J Gastroenterol 2007;22:829-34

17. Yoshida EM, Caron NR, Buczkowski AK, et al. Indications for liver transplantation in British Columbia's Aboriginal population: A 10-year retrospective analysis. Can J Gastroenterol 2000;14:775-9.

18. Moses S, Mestery K, Kaita K, Minuk GY. Viral hepatitis in a Canadian street-involved population. Can J Public Health 2002;93:123-8

19. Minuk GY, Uhanova J. Viral hepatitis in the Canadian Inuit and First Nations populations. Can J Gastroenterol 2003;17:707-12.

20. Axelrod DA, Guidinger MK, Finlayson S, et al. Rates of solid-organ wait-listing, transplantation, and survival among residents of rural and urban areas. JAMA 2008;299:202-7. 


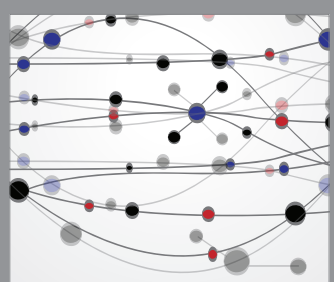

The Scientific World Journal
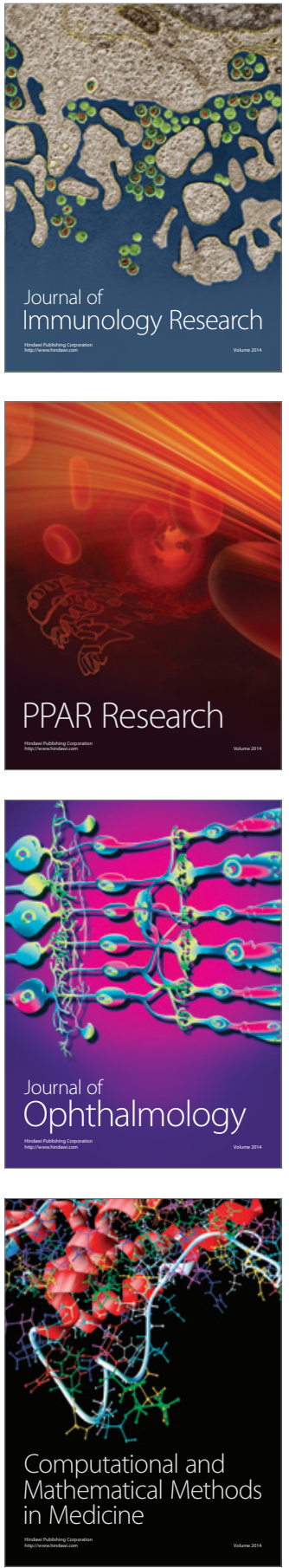

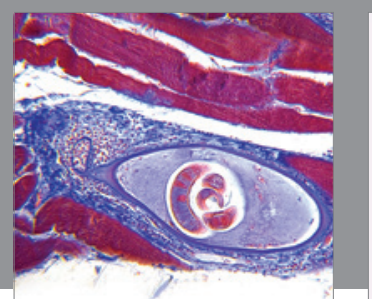

Gastroenterology Research and Practice

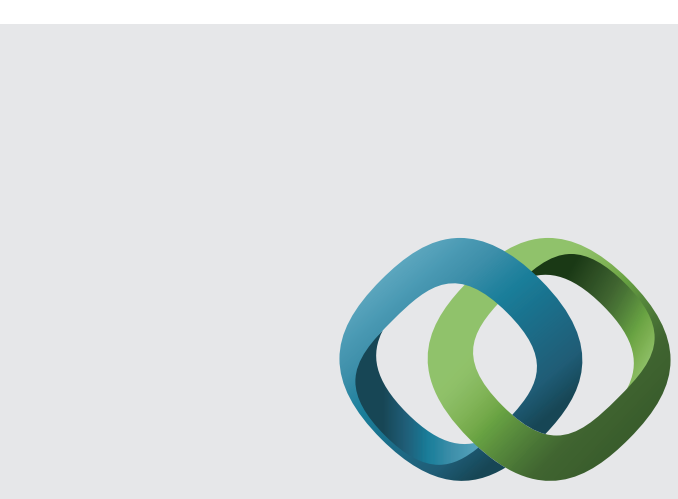

\section{Hindawi}

Submit your manuscripts at

http://www.hindawi.com
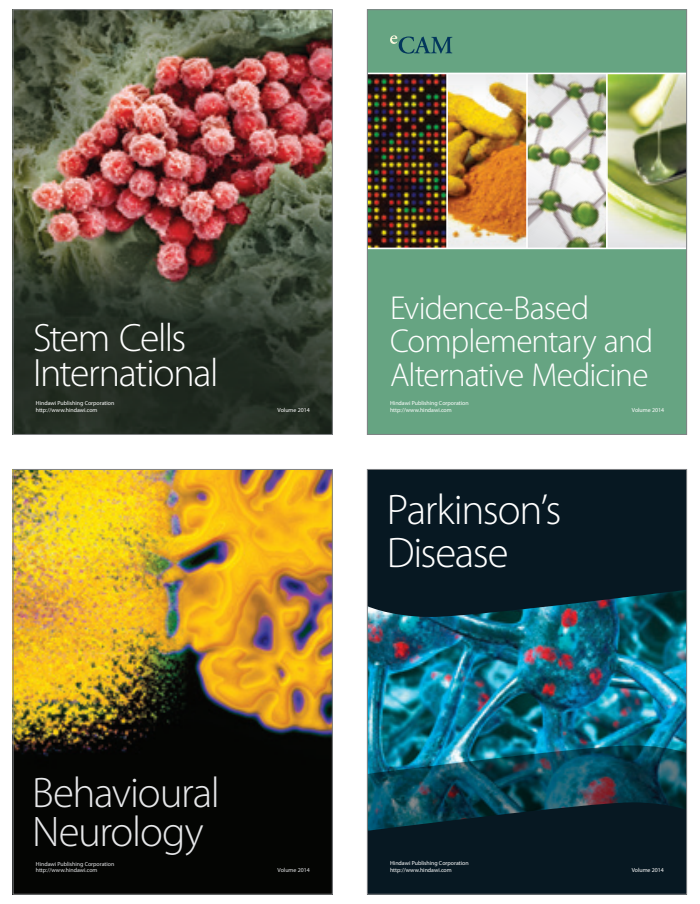
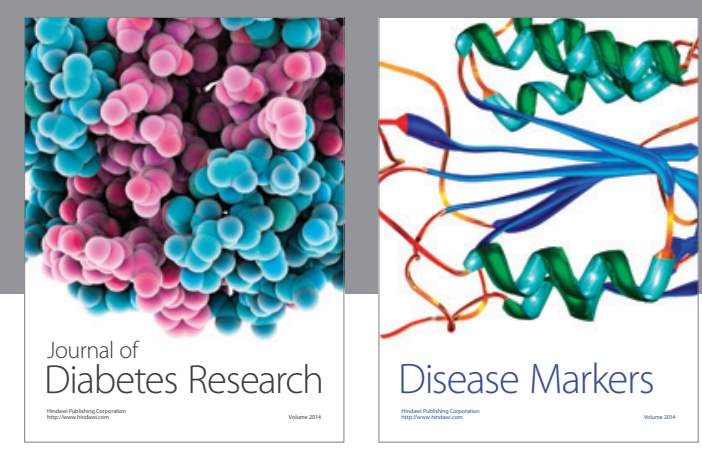

Disease Markers
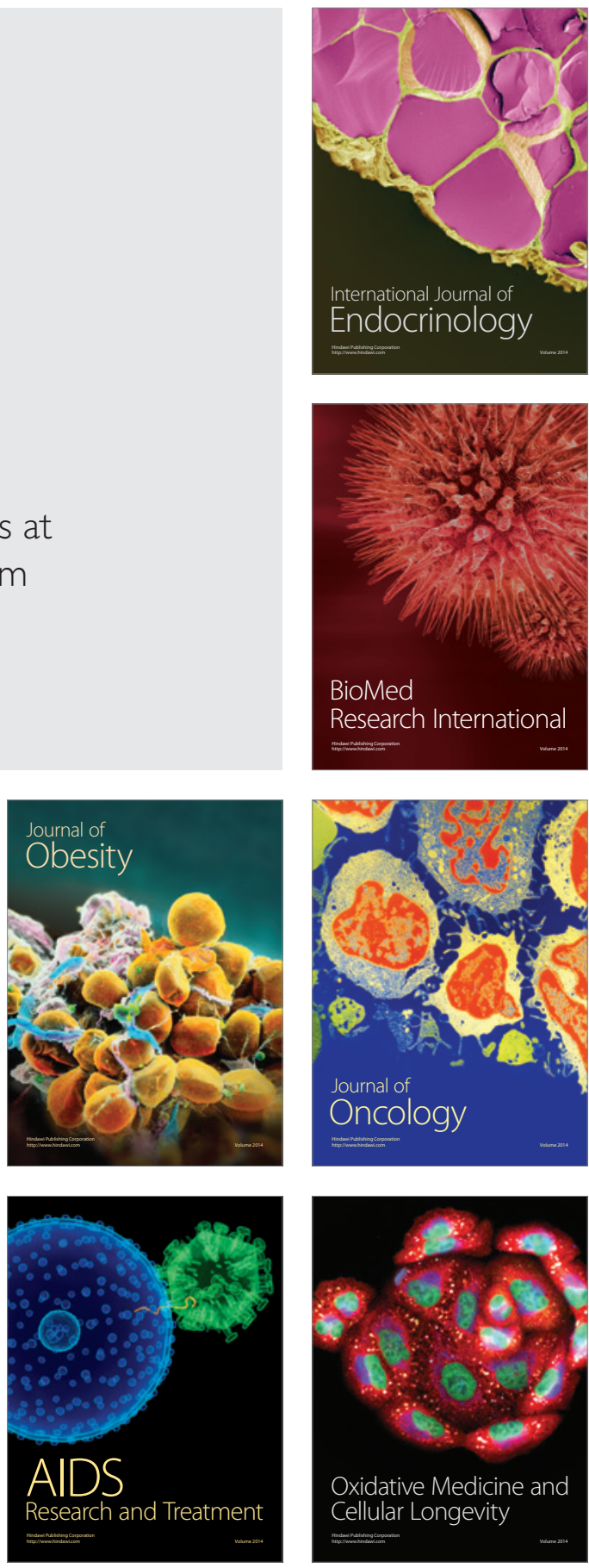